\title{
Inspirational Women in Surgery: Anne Kolbe, ONZM, MBBS (Hons), FRACS, FRCSEng (Hon), FCSHK (Hon), FRCSEd (Hon); Paediatric Surgeon, Auckland, New Zealand
}

\author{
Ian Civil ${ }^{1}$
}

Accepted: 13 September 2021/Published online: 4 October 2021

(C) Société Internationale de Chirurgie 2021

Shortly after she was elected President of the Royal Australasian College of Surgeons, Anne Kolbe was described by colleagues, friends and family as "dogged, forthright, warm, and inclusive, loves a good laugh over a card or board game, and is an organized, clear thinker who is proud to put her family ahead of her many professional roles". Those characteristics have seen Anne became one of the leading figures in Australian and New Zealand surgery over the last 20 years.

Anne Kolbe was born in Brisbane and spent much of her early life in outback Queensland. Initially schooled by correspondence, Anne attended boarding school in Brisbane from the age of 11 and was inspired to do medicine by her final year zoology teacher. These early years shaped many of Anne's values and taught her to be resourceful, resilient, diligent and perseverant.

When she indicated that she would like to study medicine, Anne faced many of the barriers that were, and still are, put in front of women wishing to undertake professional careers. In her words "this made me even more determined".

Anne Kolbe graduated from the University of Queensland with Honours in 1975. She had already met her future husband John during an elective in New Zealand prior to her final year; after graduation they moved to Adelaide for their intern year. Having decided to see the world, they set off for New Zealand in early 1977. Anne's determination and clinical capabilities saw her selected into surgical training in Auckland where she obtained her FRACS in 1984.

Ian Civil

icivil@xtra.co.nz

1 Trauma Services, Auckland City Hospital, Auckland, New Zealand
When she completed her general surgical training, Anne moved to Baltimore to train in paediatric surgery. This brought the added challenge and pleasure of engaging with families as well as patients and the responsibility of doing a good job for a child whose parents had entrusted to her care.

Anne was elected to Council of the Royal Australasian College of Surgeons in 1996 and filled a number of key educational and governance roles before being elected as President in 2003. Anne was the first female President to be elected in the College's 77-year history at that time. While she was elected on the strengths of her service to the College, her commitment to reducing barriers for women in professional roles was significant. The College recently named a room in her honour recognizing her contributions to surgery and healthcare services across Australasia and the world. Specific mention was made of her leadership on issues such as inclusion and diversity, gender equality and zero tolerance to bullying, harassment and discrimination.

Since completion of her college roles, Anne has used many of the skills that enabled her earlier achievements in subsequent governance and leadership roles in the health sector in New Zealand. Her listening skills, clarity and decisiveness are attributes that have allowed her to be successful as a Chair, Committee member and Chief Health Advisor to a wide range of national and regional health agencies. In 2006 Anne was made an Officer of the New Zealand Order of Merit for her services to medicine (Fig. 1).

Throughout her career, Anne has maintained an active practice in paediatric surgery. She enjoys people, and her interactions with patients and their families have seen her warmly regarded as a caring and compassionate clinician.

Despite her many professional achievements, her primary commitment has always been to her family. Her 


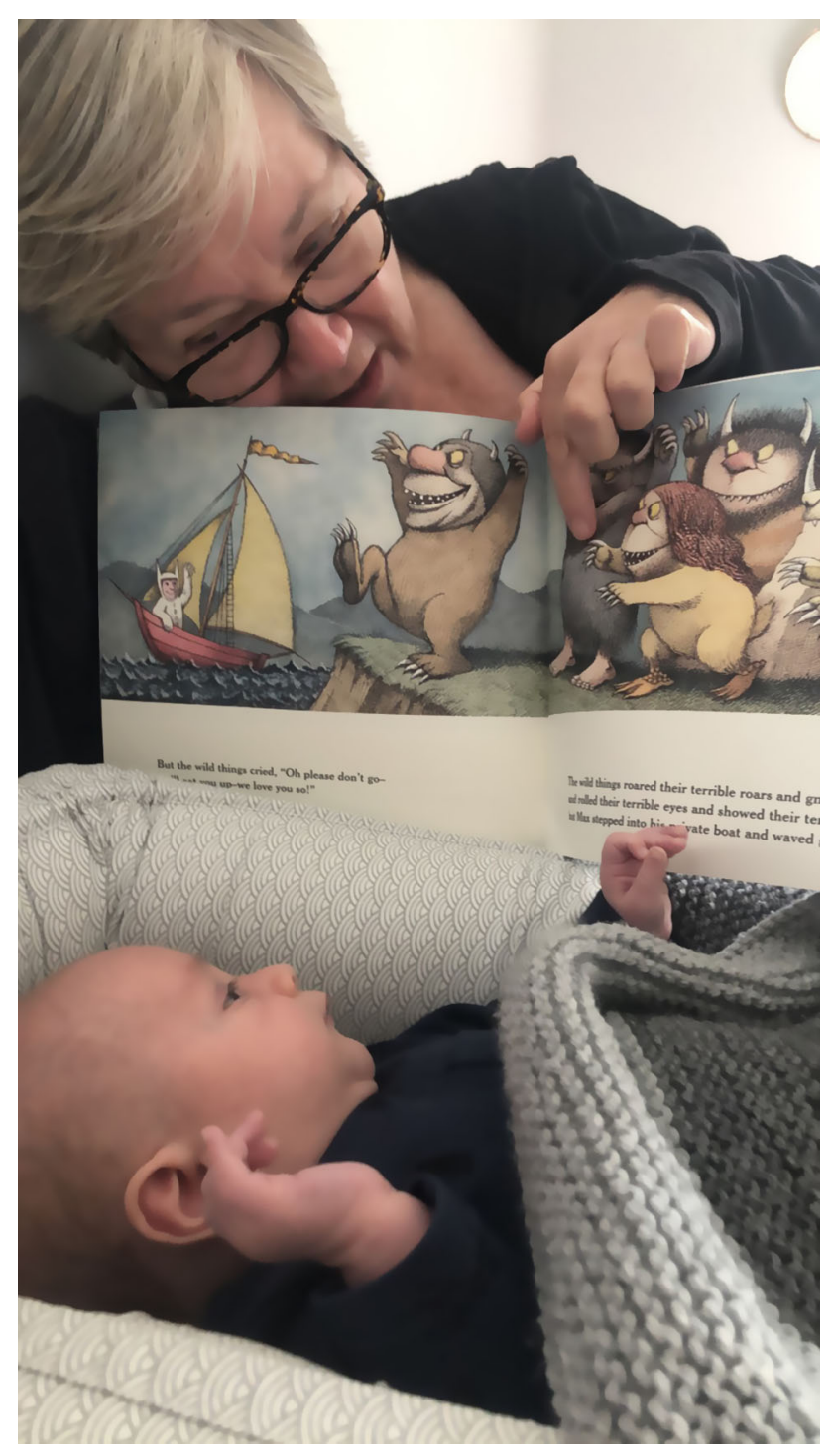

Fig. 1 Anne Kolbe reading to her grandchild relationship with them has always been Anne's number one priority, and it is the thing that she is most grateful for and most proud of. Her daughter recently posted-

"Mum, you are an individual who seamlessly blends extreme personal humility with intense professional will. You are strong, you are resilient but most importantly you are deeply thoughtful and unwaveringly kind. You have never failed to be there for your family and have shown us all first- hand what a superwoman like you is capable of! So SO proud of you"

Publisher's Note Springer Nature remains neutral with regard to jurisdictional claims in published maps and institutional affiliations. 